\title{
Comparison and Integration of Chinese and Foreign Fine Arts
}

\author{
"Shanghai School" and "Impressionist School"
}

\author{
Ying $\mathrm{Xu}$ \\ Zhuhai College of Jilin University \\ Zhuhai, China
}

\begin{abstract}
There are many striking similarities between "Shanghai school" and "impressionist school" in the social background, artistic view, existing environment and so on even they existed in the same era of different countries. However, there are also many differences due to the cultural differences. Therefore, Chinese and western fine arts could be integrated in many occasions under the overall social background.
\end{abstract}

Keywords-“Shanghai School”; "Impressionist School”; Comparison; Integration

\section{INTRODUCTION}

"Shanghai school" and "impressionist school" are the art schools that sprung up at the end of 19th century. They have great influences on French and Chinese fine arts history. "Shanghai school" is one of the major Chinese painting schools. After the Opium War, Shanghai grew to be the most vibrant commercial port within a short time of about 40 years, attracted painters from other places to gather in Shanghai and formed the center of painting, hence the name "Shanghai school". "Be tolerant to diversity" and "all-inclusiveness" are the characteristics of this school, bold in breaking the conservative barriers of Chinese painting and dared to innovate. It also has distinctive features. It has some relationship with folk art, suits both refined and popular tastes, and draws lessons from foreign arts, represented the style of the time. Xu Gu, Ren Bonian, Zhao Zhiqian, and Wu Changshuo are the representative artist of this school. In addition, Ren Xiong, $\mathrm{Hu}$ Gongshou, $\mathrm{Wu}$ Youru, Cheng Zhang, Wu Qingyun, Zhao Ziyun, Wang Zhen, and Zheng Wuchang etc., have deep influences on this school. "Impressionist school" was also called impressionism. Paris, France was the center of European oil painting in the 19th century. Painting exhibition salon was held here each year. There were many young painters full of ideal that came from different social classes and most were free men. Most of them have different opinions on the teaching method and painting style of academism. They advocated realism and sketch practice outdoors. Describe the view under outdoor daylight, and paint the instant light on canvas according the processing in his mind. This painting school mainly represents light and color. The representatives are Monet, Pissarro, Renoir, Sisley, Manet and Degas, etc.

\section{SimilaritiES BETWEEN "Shanghai SCHOOL” AND "IMPRESSIONIST SCHOOL"}

\section{A. Similar Background-Developed Business}

Paris of France is the famous romantic city in the west, as well as the capital of economy, culture and arts. "Impressionist school" sprung up during the Second French Empire ruled by Napoleon III, when the industrial revolution was at rise marked by electrification. The new technology and productive forces brought France with new economic vitality, and industry and financial industry received unprecedented development and prosperity. Artists from different countries and cities always gathered in the bars and cafes to discuss art. The new and flashy luxurious urban lives in Paris became the representation of European cultural center, and it was this kind of flashy luxurious urban life style that made the aspiring young people love nature more.

Developed in the 19th century, Shanghai was the business city that integrated economy and arts together. Since the Opium War, Shanghai became the trading port, foreign capitals were pouring in, foreign settlements were established, and rich merchants of China gathered here. Therefore, it grew up as the biggest trading port in Asia, and attracted many painters to make a living here. According to "Shanghai Painting Field" of Yang Yi, there were over 500 painters in Shanghai at the end of Qing Dynasty, from which we can see the prosperity of the art circle. Lu Xun once said in his "Two Demi-Concession Studio Essays" that, "Beijing was the imperial capital of Ming and Qing Dynasties, and Shanghai was the foreign settlements of foreign countries. Imperial capital gathered officials and foreign settlements gathered businessmen. Therefore, men of letters in Beijing were close to officials and close to businessmen in the coastal area." People who bought painting were mostly gentle merchants and rich citizens, and thus promoted the painters of "Shanghai school" to make reforms on style by breaking the traditional barrier of elegance and vulgarity.

\section{B. Artistic View - Seeking Something New and Special}

"Impressionist school" painters were against of neoclassicism according to which art was strictly constrained, against of the fact that official works not subject to "lines more superior than color" cannot be exhibited. They 
considered that kind of painting as old-fashioned, empty and with nothing new. Although they have received formal training at the beginning, most of the painters were not satisfied with the teaching and creation methods of academism, and were aspired to create a new style. They no longer took the object as the key representation, but started to seek the real feeling towards the object, as well as the representation of light, color and atmosphere. They regarded light as the "master of painting", and opposed the original color of the object. In their eyes, tree trunk was not definitely brown, and leaves not all green. Different lights could produce different colors. The mottled and gorgeous color effect, and special and light brushwork of impressionism were totally different with the classic style. In molding the image, they put sketching and image in the secondary place. There was always lack of a firm line in their works. The overturn of proper color concept and the indifference toward the solid outline of impressionist painters were the greatest resistance against conservative forces. The most representative theme of impressionism is landscape painting. They advocate nature and paint from life for seeking "instant impression" and changing effect of light and color, with the requirement of fast painting speed. For example, Monet usually took several canvas with him when painting outdoors. It took half an hour or about ten minutes to finish one piece. If it was not completed, he would continue the painting of the same view in the same perspective at the same time of the second day rather than finish at home, for the purpose of reflecting the different color of the same view in different time. They were especially subtle in the mastery of color.

"Shanghai school" dared to innovate and reform by breaking the traditional boundaries of elegance and vulgarity. They broke the traditional painting methods of the "four kings", made the best of literati painting tradition that integrated poem, calligraphy, and painting and seal together, and combined the freehand brush ink painting of the Ming and Qing Dynasties and the vigorous and robust aesthetic features of inscriptions on ancient bronzes and stone tablets. They absorbed nutrients from folk arts and suit both refined and popular tastes, both odd and folk in aesthetics. They absorbed the strong and bright color and conception of western painting. The contents of "Shanghai school" painting were auspicious and joyous, and the themes were mainly flower and birds, and then figures and then landscapes. Due to the influence of commercialization of painting, the contents were different with traditional forests and rivers that of leisure landscapes, most themes were closely related with civil lives, such as Chinese cabbage, garlic, pumpkin, carrot, persimmon, loquat, flat peach, alus spectabilis, rose, peony, yulan, chrysanthemum, canna and other things that with joy and flavor of life. The painting of "Shanghai school" painters polished a painting with water or in other method, all broad brush and wide ink. The painting method was simple and general, fast brush movement and would finish in short time.

\section{Life Circumstance - Economic Support}

The life circumstances of "impressionist school" and "Shanghai school" were similar. Both were persistent in their artistic pursuit under the poor living condition. However, they both need the support from businessmen with economic strength at their back. French painting-seller Durand-Ruel was one of the major economic support to impressionist school. With his help, painters were able to sell their works smoothly. The fact that greatly accelerated the development of impressionist school was that Durand-Ruel had edited and printed a large scale "Painting Record" in 1873 with the preface wrote by the reviewer Oman Sylvester, who has deep understanding to their art and life and gave confirmation to their works. This was a great support to the young people of the impressionist school.

In addition to maintain independent style, "Shanghai school" has to satisfy neo-capitalism's needs toward painting and reflect the public's consciousness, for the aim of guarantee good selling of their works. They needed strong and loyal fans for their lives. For example, Ren Bonian's selling of his works was related to Guangzhou merchants in Shanghai, and many paintings were painted according to the requirements of the buyer.

\section{DIFFERENCES BETWEEN "SHANGHAI SCHOOL" AND "IMPRESSIONIST SCHOOL"}

\section{A. Different Innovation Purposes}

The purpose of "impressionist school" pursuing new style was purely for overturn the old art form and advocating individuality. "Dealing theme for the color feature of the theme rather than the theme itself was the characteristics of impressionist painters that different with other schools." They considered light as the "master of painting", weaken the content and idea of the work and deviated from the real life. The innovation of "impressionist school" did not make the public accept deliberately, but centered on self feeling and displayed different aspects to the public.

The innovation of "Shanghai school" at this time reserved the thinking of the feudal officials and scholars, except for a small proportion of representing the feeling of oriental psychological harmony. It was mostly influenced by business and worldly concept. For their living and easy selling of works, the contents of Shanghai school painters must satisfy the needs of the buyer, mainly focused on flowers and birds, and endowed with joy and happiness, and moral evaluation for praying of ideal. The color of painting has rich decoration effect.

The painting speed of "impressionist school" and "Shanghai school" were all very fast, but fast for different purposes. "Impressionist school" was running with light to seek the instant reality; while "Shanghai school" was largely related to their pursuit to benefits. Their original painting method would enable them to paint many works in very short time to meet the demands of the tight market.

\section{B. Different Focus on Aesthetic Harmony}

On the surface, there are similarities in brush using between "impressionist school" and "Shanghai school", playing with brush and ink freely, and gorgeous and bright in color using. However, due to the deep rooted Chinese and 
western traditional culture, there were different focus on their pursuit of aesthetic harmony in China and western countries. In judging beauty, Chinese painters were more focused on the psychological experience of the aesthetic subject, while western painters were more focused on the external form. Chinese art creation emphasizes on expressing the emotion through natural scenery and concrete objects, with lively spirit and charm, and resemblance in spirit rather than in appearance. Subjectivity, ideological level and lyricism of the creation subject run throughout the whole processes. However, western art creation was more realistic and pragmatic, emphasized on factors of the object. For example, portrait painting of Ren Bonian was not only vivid in appearance, but also reflected the living attitude and ideal of the object. Ren Bonian have painted many works that carried feelings towards the times, such as "Guan He Zai Wang", "Guan He Yi Wang Xiao Suo", etc., bleak scenery add radiance to the depiction of the character's inner heart which is especially touching, showed the painter's deep love toward the motherland and homeland. "Painting of offering fuel in snowy weather" reflects the feeling towards life. "Guan Dao Tu" describes two excited warriors watch swords in mountain, rocks and forests, containing profound meaning.

\section{INTEGRATION OF "SHANGHAI SCHOOL" AND "IMPRESSIONIST SCHOOL"}

\section{A. "Shanghai School” Took Reference from Western Painting Skills}

Under the social and historical background that China moved to semi-feudal democratic society from feudal society, "Shanghai school" painters considered the situation by their sharp judgment, based on absorbing the essence of traditional painting and made bold innovation. They made correct judgment on the current aesthetics, abandoned the stylized and stereotyped ossified thinking of traditional painting, discarded the bad practices of literati painting, absorbed the style of folk painting and integrated the creation method of western painting, and thus the painting was quite with folk style and close to the public. Some painters of "Shanghai school" have employed the skills of western painting into their works, for example, they have made reference from the western focus perspective in the layout and composition, space structure and blank processing, and properly dealt the relationship between cavalier perspective of Chinese painting and focus perspective of western painting. In color using, they made artistic combination of Chinese traditional painting and folk painting with the western style cool and warm color, complementary color, purity, saturability and brightness. In painting skill, skeletonless painting method of bird-and-flower painting was integrated with western watercolor painting and Cunca method of landscape painting, with innovative expressive force and reach high and perfect unity in content and form. "Shanghai school" has combined the essence of Chinese traditional painting and the advantages of western painting appropriately.

\section{B. "Impressionist School" Absorbed the Oriental Painting Skill}

Japanese painting was exhibited in Paris World Expo in 1867 and 1889 that arouse severe shock in the aesthetics of European painting world. Pissarro was amazed after visited the exhibition in 1893 and wrote to his son, "Japanese exhibition was awesome. Hiroshige was an excellent impressionist painter. Not only me, but also Monet and Rodin were all enchanted by the expression effect of snow and flood. We can confirm in turn that these Japanese artists were exactly the same with our thinking." After that, there aroused a great fervor of studying Japanese Ukiyoe painting in European art circle. Monet, influenced by oriental Ukiyoe, once said, "every time when I walked into the studio of classicism, it feels like walk in the tomb." The initial painting style of Manet was realistic, and gradually changed to planarity and ornamental after influenced by the oriental painting. Different from many previous portraits Monet, the expression of flat and outline were emphasized, as well as the improvement of color brightness and sense of decoration. "Le Joueur de fifre" was one of the representative works of Monet rich in oriental taste, desalting of the background, simplification of cloth, and the comparison of red, yellow and black color were all learned from the effect of Ukiyoe. In "Les Nymphéas" of Monet, the cavalier perspective composition, smart brush and non-formalized intention expression made this work into spiritual freedom, and this kind of lyric expression was the same with Chinese freehand brush work.

\section{CONCLUSION}

In different countries at the same time, there were two painting schools in China and western country. One was the "impressionist school" that overturns classical painting skill, and one was "Shanghai school" that marked the rejuvenation of Chinese painting. Through the comparison of these two schools, we can draw the similarities and differences, and also learned that the development of art needs innovation, persistence, support and integration.

\section{REFERENCES}

[1] Li Jinfeng. The Introduction of Foreign Culture During the Late Qing Dynasty and the Early Republic of China and the Influence on Shanghai Painting School [D]. Huaibei Normal University, 2011

[2] Fan Jiaming. On the Artistic Style of Shanghai Painting School [J]. Shangqing (Research on Education and Economy), 2008

[3] Kong Xinmiao. Chinese painting Aesthetics in the 20th Century [D]. Shandong University, 2005.

[4] Dong Qingya. On the Aesthetic Pursue from Chinese and Western Painting Art [J]. China Science and Technology Review, 2014. 